\title{
Catatan Editor: Mengkaji perubahan sosial dalam perspektif psikologi sosial
}

\author{
Bagus Takwin \\ Fakultas Psikologi, Universitas Indonesia, Depok, Jawa Barat
}

Dunia begitu sering mengalami perubahan sosial, bahkan yang dramatis. Semua masyarakat mengalaminya dan jutaan orang terpengaruhi. "Perubahanperubahan sosial yang sangat cepat-adalah fakta terpenting kehidupan saat ini", begitu Nolan dan Lenski (2011, p. xiii) menyatakan. Orang-orang menerima perubahan sebagai hal yang tak terelakkan, terjadi begitu saja, meski tidak benar-benar mengerti.

Perubahan sosial menyebar luas, global, di masyarakat manapun, dan apapun kondisinya. Perubahan itu tidak terbatas pada dunia berkembang maupun dunia Barat yang dianggap lebih maju. Kita bisa temukan berbagai kajian mengenai fenomena itu sejak pertengahan abad ke-20 (diantaranya, Chirot \& Merton, 1986; Fukuyama, 1999; Greenfield, 2016; Marquis, 1947; Ponsioen, 1962; Smith, 1973; Sztompka, 1998).

Beberapa dari perubahan itu merupakan perubahan sosial yang dramatis. Kini dapat disaksikan hal tersebut banyak terjadi, diterima sebagai hal normal baru. Perubahan sosial dramatis tersebut terjadi di banyak konteks, mulai dari pergolakan politik dan ekonomi, hingga migrasi massal yang putus asa; dari bencana alam, bencana karena tindakan manusia hingga perubahan karena kemajuan teknologi. Perubahan sosial yang dramatis (dramatic social change) dicirikan oleh empat karakteristik: (1) laju perubahan sosial; (2) pecahnya struktur sosial, (3) pecahnya struktur normatif, dan (4) tingkat ancaman terhadap identitas budaya seseorang (de la Sablonnière, 2017). Sejarah mencatat perubahan sosial yang dramatis itu, seperti runtuhnya Uni Soviet, serangan teroris 9/11, kerusakan dan kerugian besar akibat Badai Katrina, serta pemberontakan "Musim Semi Arab". Lalu kini, pandemi COVID-19 terjadi. Perubahan sosial dramatis terjadi lagi, tidak hanya satu, tetapi berantai, meluas di berbagai tempat.

Studi mengenai perubahan sosial dalam bidang psikologi tergolong sedikit. Kita bisa temukan lebih banyak studi perubahan sosial di bidang sosiologi barangkali karena sosiologi memang berfokus pada perubahan sosial, jika tidak bisa dika- takan semua sosiologi adalah tentang perubahan (Sztompka, 1993; 2004). Pembahasan khusus mengenai perubahan sosial bisa ditemukan di banyak teks sosiologi (misalnya, Bauman, 2003; Giddens, Duneier, Appelbaum, \& Carr, 2011; Hewitt, White, \& Teevan, 2008; Latour, 2005). Pembahasan itu ditujukan untuk menjawab pertanyaan utama: Apa yang membuat perubahan sosial terjadi? Kebanyakan teori sosiologis itu menjelaskan berbagai proses "makro" terkait dengan permulaan revolusi, gerakan sosial, atau perubahan teknologi yang penting. Fokusnya pada faktor struktural atau peristiwa yang menentukan terjadinya perubahan sosial, termasuk perubahan sosial yang dramatis.

Studi-studi sosiologis itu berguna untuk memberikan pertimbangan tentang bagaimana perubahan sosial dibawa ke seluruh kelompok, komunitas, institusi, bangsa, bahkan masyarakat secara keseluruhan. Namun, pendekatan makro, memiliki keterbatasan yang membuat teori-teori itu tidak dapat menjelaskan aspek dan proses "mikro" dari perubahan sosial. Diperlukan penjelasan yang berfokus pada pertanyaan tentang konsekuensi perubahan sosial, tentang bagaimana anggota kelompok individual dipengaruhi oleh perubahan sosial. Di sisi lain, diperlukan juga penjelasan mengenai bagaimana individu dapat berperan sebagai faktor perubahan sosial.

Hingga saat ini, bidang psikologi sosial kekurangan penelitian empiris 'dunia nyata' mengenai perubahan sosial terutama yang mengkaji aspek dan proses mikro perubahan sosial. Kekurangan itu terjadi dalam hal teori dasar yang mungkin memberikan kerangka kerja untuk memandu penelitian psikologi sosial, juga teori turunan yang lebih khusus menjelaskan fenomena yang tercakup dalam perubahan sosial. Sejauh ini, psikologi secara umum, dan psikologi sosial secara lebih khusus, belum dapat mengatasi masalah perubahan sosial secara memadai, apalagi perubahan sosial yang dramatis.

Ada kebutuhan untuk membangun dan merumuskan kerangka teoretis baru yang mampu menjelaskan perubahan sosial dan dampaknya

Naskah diterima: 20 Agustus 2021

*Fakultas Psikologi, Universitas Indonesia, Kampus UI, Depok, Jawa Barat, Indonesia, 16424 E-mail: bagus-t@ui.ac.id 
pada tingkat individu. Itu dibutuhkan untuk dapat mengatasi masalah dihasilkan perubahan sosial, terutama mengatasi dampak buruknya bagi individu. Mengingat konsekuensi perubahan sosial dramatis berpotensi mengerikan, para psikolog sosial perlu mementingkan topik ini dan melakukan kajian dengan standar akademis yang ketat. Realitas globalisasi yang luas saat ini dan imigrasi besar-besaran, serta banyak kejadian tanpa preseden yang dapat menghasilkan perubahan sosial dramatis makin menguatkan kebutuhan itu. Psikologi sosial perlu berfokus ke dampak perubahan sosial pada kesejahteraan individu, serta mekanisme adaptasi yang dikembangkan orang ketika menghadapi perubahan sosial. Sejauh ini, itu sebagian besar masih belum diketahui (Pinquart \& Silbereisen, 2004; Kim, 2008; Liu et al., 2014). Kondisi ini menuntut psikologi sosial untuk fokus pada psikologi perubahan sosial sebagaimana yang disarankan oleh beberapa peneliti (de la Sablonnière et al., 2013; de la Sablonnière \& Usborne, 2014). Ini mengingatkan juga pada Tajfel (1972) yang menyatakan bahwa secara ideal isu sentral dari psikologi sosial adalah proses-proses yang menyertai, menentukan dan dipengaruhi oleh perubahan sosial.

Dalam perberbendaharaan psikologi, kajian mengenai perubahan sosial sudah cukup lama dilakukan. Makalah pertama tentang perubahan sosial diterbitkan di Academy of Political and Social Science lebih dari 70 tahun lalu, berjudul Psychology of Social Change (Marquis, 1947). Di situ perubahan sosial didefinisikan sebagai proses yang selalu lambat dan bertahap. Definisi ini sudah tidak memadai sebab kini kita saksikan berbagai perubahan sosial yang terjadi secara cepat dan dramatis. Setelah itu, hanya beberapa psikolog yang terisolasi dan tidak mengemuka yang berfokus pada perubahan sosial dan lebih sedikit lagi yang menawarkan definisi atau konseptualisasi konsep yang jelas.

Hingga kini, belum ada penjelasan mengenai hubungan antara proses "makro" perubahan sosial dan proses "mikro" dari dampak psikologisnya. Belum ada yang menjembatani kedua hal itu. Diperlukan kajian yang berfokus pada konseptualisasi perubahan sosial yang mencakup proses makro dan mikro untuk memahami adaptasi individu terhadap perubahan sosial. Diperlukan konseptualisasi perubahan sosial yang dapat menjadi jembatan itu. Ini bisa jadi merupakan tantangan tersulit mengingat kompleksitas dari gejala perubahan sosial, juga sejauh ini belum tercapai konsensus mengenai konseptualisasi dan pemahaman tentang perubahan sosial dalam literatur ilmiah. Namun ini adalah langkah pertama yang dibutuhkan untuk bergerak menuju psikologi perubahan sosial. Kita perlu model-model teoritis yang menghubungkan karakteristik perubahan sosial bersama-sama dengan mempertimbangkan berbagai konteks sosial.

Belakangan ini, ada gerakan yang berkembang dalam psikologi untuk meneliti perubahan sosial. Mereka secara lebih eksplisit membuat hubungan antara bagaimana perubahan di tingkat masyarakat berdampak pada orangorang dan bagaimana kelompok orang tertentu menjadi semakin tertindas dan terpinggirkan oleh pilihan politik dan ekonomi. Salah satu kelompok yang fokus pada studi ini adalah para peneliti psikologi komunitas yang berusaha menciptakan perubahan sosial positif dalam struktur sosial. Mereka mau menerima tantangan untuk mengembangkan teori psikologi perubahan sosial. Usaha-usaha mereka dilakukan untuk memperoleh pemahaman mengenai dampak perubahan sosial pada individu. Selain itu, sudah dimulai juga usaha untuk menghasilkan penjelasan yang diharapkan dapat menjembatani perbedaan epistemologis antara teori, bidang penelitian dan perspektif teoritis yang berbeda dalam meneliti perubahan sosial. Selain itu, mereka juga mengidentifikasi konseptualisasi yang jelas tentang perubahan sosial yang mempertimbangkan dan mencakup karakteristik berbeda yang menyusunnya.

Studi tentang perubahan sosial juga menjadi tantangan bagi psikolog sosial di Indonesia. Berbagai perubahan sosial banyak terjadi di Indonesia, berdampak signifikan pada orang-orangnya. Pandemi COVID-19 telah menghasilkan perubahan sosial yang besar dan dramatis. Dampaknya juga besar dan dramatis. Barangkali ini bisa jadi panggilan bagi para psikolog sosial Indonesia untuk meneliti dan menghasilkan kontribusi yang bisa mengatasi masalah perubahan sosial. Lebih jauh lagi, diharapkan nantinya para psikologi sosial dapat menerapkan hasil studi mereka pada kebijakan dan tindakan politik yang terkait dengan dampak perubahan sosial.

\section{Referensi}

Bauman, Z. (2003). Liquid Love: On the Frailty of Human Bonds. Cambridge: Polity Press. 
Chirot, D., and Merton, R. M. (1986). Social Change in the Modern Era. San Diego, CA: Harcourt Brace Jovanovich.

de La Sablonnière, R., Bourgeois, L. F., \& Najih, M. (2013). Dramatic social change: A social psychological perspective.Journal of Social and Political Psychology, 1(1), 253-272. https://doi.org/10.5964/jspp.v1i1.14

de la Sablonnière, R., \& Usborne, E. (2014). Toward a social psychology of social change: insights from Identity Process Theory. Identity process theory: identity, social action and social change, 203-221.

de la Sablonnière, R. (2017). Toward a psychology of social change: A typology of social change. Frontiers in psychology, 8, 397. https://doi.org/10.3389/fpsyg.2017.00397

Fukuyama, F. (1999). The Great Disruption: Human Nature and the Reconstitution of Social Order. New York, NY: Free Press.

Giddens, A., Duneier, M., Appelbaum, R. P., \& Carr, D. (2011). Introduction to Sociology, 8th Edn. New York, NY: Norton Publishing.

Greenfield, P. M. (2016). Social change, cultural evolution, and human development. Curr. Opin. Psychol. 8, 84-92. https://doi.org/10.1016/j.copsyc.2015.10.01 2

Hewitt, W. E., White, J., \& Teevan, J. J. (2008). Introduction to Sociology: A Canadian Focus, 8th Edn. Toronto, ON: Pearson Prentice Hall.

Kim, J. (2008). Perception of social change and psychological well-being: a study focusing on social change in Korea between 1997 and 2000. J. Appl. Soc. Psychol. 38, 2821-2858. https://doi.org/10.1111/j.15591816.2008.00415.x

Latour, B. (2005). Reassembling the Social: An Introduction to Actor-Network-Theory. New York, NY: Oxford University Press.

Liu, H., Li, S., Xiao, Q., and Feldman, M. W. (2014). Social support and psychological well-being under social change in urban and rural China.Soc. Indic. Res. 119, 979-996. https://doi.org/10.1007/s11205-013-05341

Marquis, D. G. (1947). Psychology of social change. The Annals of the American Academy of Political and Social Science, 249(1), 75-80.

Nolan, P., and Lenski, G. E. (2011). Human Societies: An Introduction to Macrosociology, 11th Edn. Boulder, CO: Paradigm.

Pinquart, M., and Silbereisen, R. K. (2004). Human development in times of social change: theoretical considerations and research needs. Int. J. Behav. Dev. 28, 289-298. https://doi.org/10.1080/016502503440004 06

Ponsioen, J. A. (1962). The Analysis of Social Change Reconsidered: A Sociological Study. The Hague: Mouton.

Smith, A. D. (1973). The Concept of Social Change: A Critique of the Functionalist Theory of Social Change. London: Routledge and Kegan Paul.

Sztompka, P. (1993). The Sociology of Social Change. Oxford: Blackwell.

Sztompka, P. (1998). Devenir social, néomodernisation et importance de la culture: quelques implications de la révolution anticommuniste pour la théorie du changement social. Sociologie et sociétés, 30(1), 85-94. https://doi.org/10.7202/001781ar

Sztompka, P. (2004). "The trauma of social change: a case of postcommunist societies," in Cultural Trauma and Collective Identity, eds J. C. Alexander, R. Eyerman, B. Giesen, N. J. Smelser, and P. Sztompka (Berkeley, CA: University of California Press), 155-195.

Tajfel, H. (1972). Experiments in a Vacuum. In J. Israel, \& H. Tajfel (Eds.), The Context of Social Psychology A Critical Assessment (pp. 69-119). 